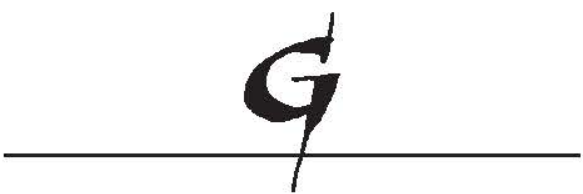

THE GEORGE GUND FOUNDATION IMPRINT IN AFRICAN AMERICAN STUDIES

The George Gund Foundation has endowed this imprint to advance understanding of the history, culture, and current issues of African Americans. 
The publisher gratefully acknowledges the generous support of the African American Studies Endowment Fund of the University of California Press Foundation, which was established by a major gift from the George Gund Foundation. 
Spaces of Conflict, Sounds of Solidarity 


\section{AMERICAN CROSSROADS}

Edited by Earl Lewis, George Lipsitz, George Sánchez, Dana Takagi, Laura Briggs, and Nikhil Pal Singh 


\section{Spaces of Conflict, Sounds of Solidarity}

Music, Race, and Spatial Entitlement in Los Angeles

Gaye Theresa Johnson

甲

UNIVERSITY OF CALIFORNIA PRESS

Berkeley • Los Angeles • London 
The publisher gratefully acknowledges the generous support of the Lisa See Endowment Fund in Southern California History and Culture of the University of California Press Foundation.

University of California Press, one of the most distinguished university presses in the United States, enriches lives around the world by advancing scholarship in the humanities, social sciences, and natural sciences. Its activities are supported by the UC Press Foundation and by philanthropic contributions from individuals and institutions. For more information, visit www.ucpress.edu.

University of California Press

Berkeley and Los Angeles, California

University of California Press, Ltd.

London, England

(C) $20 I_{3}$ by The Regents of the University of California

Library of Congress Cataloging-in-Publication Data

Johnson, Gaye Theresa.

Spaces of conflict, sounds of solidarity : music, race, and spatial entitlement in Los Angeles / Gaye Theresa Johnson.

p. $\mathrm{cm}$.

Includes bibliographical references.

ISBN 978-0-520-27527-0-ISBN 978-0-520-27528-7

I. Los Angeles (Calif.)-Race relations-History.

2. Minorities-California-Los Angeles-Social

conditions. 3. Minorities-Political activity-

California-Los Angeles-History. 4. Community

development-California-Los Angeles-History.

5. Popular music-Social aspects-California-Los

Angeles. 6. Los Angeles (Calif.)-Social conditions.

I. Title.

F869.L89A2533 20I3

979.4'94-dc23 20I20398I3

Manufactured in the United States of America

$\begin{array}{lllllllllll}22 & 2 \text { I } & 20 & \text { I9 } & \text { I } 8 & \text { I7 } & \text { I6 } & \text { I5 } & \text { I4 } & \text { I3 } \\ \text { I0 } & 9 & 8 & 7 & 6 & 5 & 4 & 3 & 2 & \text { I } & \end{array}$

In keeping with a commitment to support environmentally responsible and sustainable printing practices, UC Press has printed this book on Rolland EnviroIoo, a I0०\% post-consumer fiber paper that is FSC certified, deinked, processed chlorine-free, and manufactured with renewable biogas energy. It is acid-free and EcoLogo certified. 
For Mary Ella and Theresita, for Shanti and Fauna, for Clyde ... with thanks.

For Juanita and Hymon, for abiding love and faith. For Chuck and our Cayeloncita, for always. 